\title{
Pedagogické přístupy a didaktické postupy zaměřené na volnočasovou kompetenci
}

\author{
Anna Dudová, ${ }^{a}$ \\ Richard Macküb
}

Kontakt

a,b Jihočeská univerzita v Českých Budějovicích Teologická fakulta Kněžská 8 37001 České Budějovice Česká republika

a dudova@tf.jcu.cz

bmackur@tf.jcu.cz

\begin{abstract}
Abstrakt: Studie nabízí přehled používaných pedagogických přístupů a didaktických postupů ve školských zařízeních pro zájmové vzdělávání (školní družiny, školní kluby, domy dětí a mládeže) a hodnotí je z hlediska rozvoje oblasti výchovy k volnému času, jejímž obecným cílem je volnočasová kompetence. $\mathrm{V}$ úvodní části autoři vysvětlují základní pojmy. První (nejrozsáhlejší) kapitola se zaměřuje na výchovu ve volném čase (mimoškolní výchova, výchova mimo vyučování). $\mathrm{Na}$ informace o různých převážně tradičních metodách navazuje oddíl věnovaný metodám vycházejícím z konstruktivistické pedagogiky. První kapitolu uzavírá část věnovaná metodám užívaným v tzv. otevřené práci s mládeží (Offene Jugendarbeit, Open Youth Work). Druhá kapitola je věnována pojmu volnočasová kompetence a třetí kapitola obsahuje zhodnocení edukačních metod $z$ hlediska jejich vhodnosti ve výchově zaměřené na volnočasovou kompetenci.
\end{abstract}

Klíčová slova: výchova ve volném čase, výchova k volnému času, volnočasová kompetence, klíčové kompetence, didaktické metody $v$ zájmovém vzdělávání, konstruktivistické přístupy, animace, pedagogika sociálního prostoru, informal education

\section{Pedagogical approaches and didactic procedures focused on leisure literacy}

\begin{abstract}
The article offers an overview of the pedagogical approaches and didactic procedures used for leisure education in school facilities (after-school club, school clubs, children's and youth homes) and evaluates them in terms of the development of leisure education, whose general goal is leisure literacy. In the introductory part, the authors explain the basic concepts. The first (most extensive) chapter is focused on education (extracurricular education, education outside teaching). Information on various methods, mostly traditional, is followed by a section devoted to methods based on constructivist pedagogy. The first chapter concludes with a section devoted to the methods used in so-called open youth work (Offene Jugendarbeit, Open Youth Work). The second chapter is devoted to the concept of leisure competence, and the third chapter contains an evaluation of educational methods in terms of their suitability for education focused on leisure literacy.
\end{abstract}


Keywords: leisure education, education for leisure, leisure literacy, key competencies, didactic methods in leisure education, constructivist approaches, animation, pedagogy of the social space, informal education

\section{1 Úvod}

Jestliže chápeme, že předmětem pedagogiky volného času (jako pedagogické subdisciplíny) není pouze výchova ve volném čase, ale také výchova skrze volnočasové aktivity (education through leisure) a výchova k volnému času (education for leisure), ptáme se také po edukačních cílech, které vycházejí z těchto přístupů. Proto také pro úvahy o metodách, které používají (nebo mohou používat) učitelé, vychovatelé a pedagogové volného času ${ }^{1}$ ve výchovném působení souvisejícím s volným časem, vycházíme z této trojice: výchova ve volném čase, skrze volný čas a k volnému času (Hofbauer, 2004).

Ačkoliv se o těchto třech pojetích pedagogiky volného času zmiňoval Břetislav Hofbauer už bezmála před dvaceti lety, bylo zatím ve středu zájmu českých vychovatelů a pedagogů volného času pouze jedno $z$ těchto pojetí, a to výchova ve volném čase.

Volný čas dětí se totiž - zcela ve smyslu dřivější „výchovy mimo vyučování“ - chápal pouze jako čas, který je možno efektivně využít k tomu, aby dítě "rozvíjelo svoje zájmy“, at' už sportovní, umělecké, technické, anebo jiné. Jako by se zapomnělo, že sama zábava a kamarádské kontakty děti rozvíjejí, takže můžeme právem mluvit i o „výchově skrze volný čas". V tomto př́spěvku se však chceme zaměřit výhradně na výchovu $k$ volnému času, jejiž obecný cíl můžeme označit pojmem volnočasová kompetence (Freizeitkompetenz, leisure literacy).

S pojmem volnočasová kompetence se setkáváme od konce 80 . let minulého století. Jako cíl ji definoval Opaschowski, který vycházel z pozitivní definice volného času a z pozitivního definování svobody: „Volný čas je čas, v němž je člověk pro něco svobodný“ (Opaschowski, 2006, s. 35). Z toho vyplývá, že člověk by měl být schopen samostatně disponovat se svým (volným) časem a rozhodovat se o jeho naplnění.

Jak se má člověk naučit samostatně plánovat, rozhodovat a utvářet volný čas? Nejde to samo. A proto by se učení volnočasové kompetenci mělo stát nedílnou součástí práce pedagogů (a to nejen pedagogů volného času!). Je důležité, aby si člověk uvědomoval význam svého (volného) času. $\mathrm{A}$ to $\mathrm{z}$ mnoha důvodů: volný čas (leisure) může a má vést $\mathrm{k}$ osobní spokojenosti a $\mathrm{k}$ obohacení a poskytuje mnoho př́ležitostí $k$ naplnění osobních potřeb a zálib. $U$ nás nejznámější definice volnočasové kompetence pochází od Opaschowského: „Volnočasová kompetence je schopnost správně nakládat s volným časem, ale také schopnost jako uspořádat a dobře prožít svůj život" (Kaplánek, 2012, s. 104, 2017, s. 112).

Pávková nepřejímá Opaschowského termín volnočasová kompetence, ale přitom uvažuje podobně: za podstatu výchovy pro volný čas ( $k$ volnému času) považuje "utváření, rozvíjení a kultivování schopností, dovedností, motivace a kompetencí pro hodnotné využívání volného času" (Hájek et al., 2008 , s. 74). Metodika pro podporu tvorby školního vzdělávacího programu ve školských zařizeních pro zájmové vzdělávání z roku 2007 zase hovoří „o klíčových kompetencích k naplnění volného času“, pod kterými rozumí schopnost rozumně, aktivně využívat volný čas, vybírat přiměřené volnočasové

1 Zatímco výraz pedagogika se $v$ české odborné pedagogické literatuře používá pro označení vědy, která zkoumá, popisuje, reflektuje a rozvijí edukační realitu, výraz pedagog je označením pro nositele různých pedagogických profesí (učitel, asistent pedagoga, vychovatel atd.); proto je také označením profese vychovatele a organizátora volného času ve školských zařízeních pro zájmové vzdělávání. Následkem tohoto kolísání kolísá také význam slova „pedagogika volného času“. Tento výraz totiž neoznačuje pouze reflexi edukačních aktivit spojených s volným časem, nýbrž často také praktickou činnost pedagogů volného času, podobně jako je tomu třeba u speciální pedagogiky nebo sociální práce. 
aktivity, organizovat a ř́dit vlastní volný čas, odmítnout nevhodné aktivity atd. Přes všechny tyto definice a prohlášení se můžeme - jako pedagogové - ptát: Co děláme v dnešní (volnočasové) pedagogické praxi, abychom mohli říct, že rozvíjíme schopnost dětí utvářet si svobodně (nezávisle) a odpovědně svůj volný čas na základě reflektovaných hodnot, postojů, potřeb a zálib?

$\checkmark$ rámci projektu Prožívání volného času dětí staršího školního věku jako výzva pro pedagogiku (TL02000387; TA ČR Starfos, n.d.) $)^{2}$ hledáme vhodné metodické postupy $\mathrm{k}$ dosažení tohoto cíle $u$ dětí ve věku 11-15 let. Východiskem pro naše hledání je pojetí volnočasové kompetence formulované německými pedagogy Opaschowským a Nahrstedtem. Volnočasově kompetentní nebo volnočasově zralý je podle autorů každý člověk, který umí svobodně a samostatně nakládat se svým volným časem, a to $v$ kontextu celého svého života a jeho smyslu. Oba autoři nekladou tolik důraz na volný čas jako takový, ale spíše na svobodu, protože volný čas můžeme chápat jako „čas svobody" a pro současného člověka je rovněž symbolem svobody (Nahrstedt, 1974).

Jsme si vědomi toho, že základem volnočasové kompetence jsou znalosti a dovednosti, které uschopňují děti i dospělé uspokojivým způsobem realizovat volnočasové aktivity (leisure skills). Proto učíme děti uspořádat si volný čas, vybírat si volnočasové nabídky dle svého zájmu a rozvíjet jejich prostrednictvím komunikační a sociální dovednosti. Cílem tohoto článku je popsat metody pedagogiky volného času a jejich použitelnost ve výchově $\mathrm{k}$ volnému času.

\section{Metody školní a mimoškolní výchovy a vzdělávání}

Klasifikace metod je vpedagogice volného času rozpracována bud' málo, nebo nevhodně. $\checkmark$ české literatuře je poměrně obtížné vůbec nalézt komplexně pojatý přehled metod výchovy ve volném čase. Většina z autorů ve svých dílech vychází z rozdělení jednotlivých forem výchovné práce ve volném čase a konkrétní metody pak vztahuje $\mathrm{k}$ těmto formám.

Zatímco Hájek et al. (2008) rozlišil metody běžným způsobem na slovní, názorné a praktických činností, někteří jiní čeští autoři (Kaplánek, 2017) se ve výčtu metod pedagogiky volného času opírali o Opaschowského (1996). V 70. letech dvacátého století se totiž v Německu mluvilo o sedmi metodách: volnočasové poradenství, animace volnočasových aktivit, vývoj volnočasových profesí, plánování volného času, administrace volného času, výzkum volného času, nauka o volném času. Je však třeba upozornit na to, že se jedná zčásti o obecné pedagogické metody, takže sám Opaschowski označil jako vlastní metody pedagogiky volného času pouze tři: informativní poradenství, komunikativní animaci a participativní plánování.

Metodou (řec. methodos) rozumíme každý plánovitě užitý postup, který slouží k dosažení nějakého cíle (Bakešová, 2009), metodou v rámci výchovy ve volném čase pak - analogicky k tomu, co uvádí Průcha (2009) - systém edukačních činností pedagoga a účastníků edukačního procesu směřující k dosažení stanovených edukačních cílů.

Často se setkáváme se zaměňováním pojmů metoda a přístup. Na rozdíl od metody rozumíme přístupem ideový (hodnotový), obsahový a organizační základ (Bauman, 2006), podle něhož volíme vhodný soubor metod. Přístup je tedy pojem nadřazený metodám, nebot' nejenže umožňuje vytvářet specifické (i když do jisté míry se překrývající) soubory metod, ale dodává jim také konkrétní ideová východiska.

2 Tento projekt je podpořen Technologickou agenturou České republiky (TAČR) v rámci projektů Éta (TL02000387; TA ČR Starfos, n.d.). Cílem projektu je na základě multidisciplinárního př́stupu založeného na pedagogickém a sociologickém výzkumu stanovit pedagogické výzvy a na ně navazující strategie a konkrétní vzdělávací programy, které povedou ke zvýšení volnočasové kompetence dětí staršího školního věku, tj. jejich schopnosti kritičtěji vyhodnocovat to, jak nakládat se svým (volným) časem, rozhodovat se pro kvalitní prožití volného času, a tím zvyšovat resilienci vưči sociálněpatologickým formám trávení volného času. 


\subsection{Didaktické metody v zájmovém vzdělávání}

Pro potřeby naší reflexe metod z hlediska výchovy k volnému času jsme vycházeli z výukových metod podle Maňáka (1990) a adaptovali jsme je pro volnočasová edukační prostředí (Tabulka 1). S baterií těchto metod jsme následně provedli sondu mezi vychovateli školních družin a školních klubů.

Tabulka 1

Metody výchovy ve volném čase ve vztahu $k$ metodám výukovým

\begin{tabular}{|c|c|c|}
\hline \multicolumn{2}{|c|}{$\begin{array}{l}\text { Výukové metody z hlediska pramene poznání a typu } \\
\text { poznatků - aspekt didaktický }\end{array}$} & \multirow{2}{*}{$\begin{array}{l}\text { Metody výchovy ve volném čase } \\
\text { Výklad/popis, vyprávění }\end{array}$} \\
\hline Metody slovní & $\begin{array}{l}\text { Monologické metody } \\
\text { (popis, vysvětlování, vyprávění, } \\
\text { přednáška, výklad) }\end{array}$ & \\
\hline & $\begin{array}{l}\text { Dialogické metody } \\
\text { (rozhovor, diskuse, dramatizace) }\end{array}$ & Diskuse \\
\hline & Metody práce s učebnicí, knihou & Práce s knihou/texty \\
\hline \multirow[t]{3}{*}{$\begin{array}{l}\text { Metody názorné } \\
\text { demonstrační }\end{array}$} & $\begin{array}{l}\text { Pozorování předmětů a jevů, } \\
\text { předvádění (předmětů, modelů, } \\
\text { pokusů, činností) }\end{array}$ & Předvádění/názorná demonstrace \\
\hline & Demonstrace obrazů statických & \\
\hline & Projekce statická a dynamická & \\
\hline \multirow[t]{7}{*}{ Metody praktické } & $\begin{array}{l}\text { Nácvik pohybových a pracovních } \\
\text { dovedností }\end{array}$ & Pohybové činnosti \\
\hline & Žákovské laborování & \\
\hline & $\begin{array}{l}\text { Pracovní činnosti } \\
\text { (v dílnách, na pozemku) }\end{array}$ & Manuální činnosti \\
\hline & Grafické a výtvarné činnosti & \\
\hline & - & Expresivní činnosti \\
\hline & & (dramatizace, hudba, zpěv apod.) \\
\hline & - & Hra \\
\hline
\end{tabular}

K uvedenému přehledu (Tabulka 1) je třeba doplňujícího komentáře. Zejména je třeba uvést, že klasifikaci záměrně terminologicky i fakticky přibližujeme výchově tzv. mimoškolní. Jde tedy doslova o metody výchovy ve volném čase. Jak však naznačujeme $v$ dalších částech textu, tato klasifikace není jedinou možnou s ohledem na tu dimenzi pedagogiky volného času, která na rozdíl od výchovy ve volném čase reflektuje spíše výchovu $k$ volnému času, přesněji k tzv. volnočasové kompetenci.

\subsection{Konstruktivistické prrístupy}

Každá použitá metoda, každá aktivita, kterou pedagog nabídne, působí inspirativně a do určité míry posiluje volnočasovou kompetenci, protože rozšiřuje portfolio všech potenciálně realizovatelných činností ve volném čase. Avšak jen některé z metod umožňují účastníkům vkládat do obsahu prováděné činnosti vlastní smysl, a tím budovat potřebnou schopnost odlišování smyslu-plného od smyslu-prostého, či dokonce nesmysIného konání. Nejen že takové metody umožňují smysl hledat, ale do velké míry také procesně napomáhají, jak se takovému hledání učit.

$\checkmark$ této kapitole se zaměříme na několik metod, které můžeme pojmout také $v$ kontextu konstruktivistické pedagogiky ${ }^{3}$. Kromě hry, diskuse (dialogu) a reflexe se v této kapitole zaměříme také

3 Pro podrobnější výklad konstruktivistické pedagogiky není v této studii prostor, proto se omezme na konstatování, že př́vlastkem „konstruktivistický“ chceme naznačit, že dané paradigma je založeno 
na prožitkově-zkušenostní dimenzi pedagogického procesu. Nehovoříme o nich již jako o metodách, ale spíše jako principech, které pedagogům dávají př́ležitost přirozeně budovat způsobilost zodpovědně se rozhodovat o otázkách nakládání s volným časem.

\subsubsection{Hra}

V českém edukačním prostředí je hra stále ještě alternativním prostředkem formálního vzdělávání; jinak je tomu ve sféře neformálního vzdělávání. Hry pomáhají simulovat problémové situace, vytvářet nové, kreativní situace a fiktivní kontexty, a tak zprostředkovávají nové cesty řešení a s nimi i učení. Unikátnost hry spočivá ve skutečnosti, že hra funguje jako zrcadlo reality. Podle Finka takový zrcadlový obraz, at už prírodní, či umělý, vykazuje jistou neskutečnost: je sice reálným objektem v reálném čase, avšak pro zrcadlení je stále třeba přítomnost originálu. Hra je tedy čímsi neskutečným ve skutečném světě. Tento fakt pak způsobuje určitou nevážnost herních situací: „Nevážnost hry spočívá v tom, že iluzivním způsobem napodobuje vážnost života“ (Fink, 1993, s. 95). Tak hráči získávají také možnost zaujmout odstup, měnit svoje stanovisko a být kreativní při řešení různých situací. Hra má účastníkům umožnit dril nebo dopomoci k získání nové či modifikaci stávající zkušenosti. Děje se tak skrze reflexi, tedy v duchu konstruktivistické snahy postupného budování vlastního poznání účastníkem samotným.

Dualita skutečného a herního světa ve své podstatě odráží přistup pedagoga (který hru jakoby redukuje na prostředek $\mathrm{k}$ dosažení cíle, jenž má $v$ reálném světě nezpochybnitelnou hodnotu) a př́istup hráče (který, pokud si skutečně hraje, vnímá odlišný raád věcí a jinak nelogické počínání mu v kontextu hry dává vlastní smysl). Borecký (2005) proto rozlišuje tzv. reduktivní a restitutivní př́stup ke hře.

Restitutivní prístup je více o hraní, odkazuje na prímý prožitek hrajícího si, jeho vztah ke světu a schopnost imaginace. Tohoto hraní se hráč nedopustí pouhým sledováním herních pravidel, ale jde o svobodné překročení hranic reálného a imaginárního herního světa. $V$ ten okamžik hra žákům umožňuje zprostředkovat poutavější a smysluplnější učební zážitek a podpořit jeho dlouhodobý efekt. Probouzí totiž vnitřní motivaci, svou podstatou založenou na vykonávání činnosti, která je vnímána jako příjemná, zajímavá a sama o sobě uspokojující. Ve své přehledové studii to dokládají např. Lumsden et al. (2016), když uvádí, že použití herních prvků přispívá ke zvýšení vnitřní motivace.

Naproti tomu $v$ reduktivním prístupu vnímáme hru jako nástroj, mechanismus, soubor pravidel a funkcí. Tyto však bezpodmínečně také ovlivňují potenciál hry probudit vnitřní motivaci, a jsou tak nástrojem pedagoga, který může skrze vhodnou modifikaci hry (nebo vytvořením nové hry) získat efektivní edukační prostředek. Hovoříme zde o hře ve významu game (Mead, 1934), tj. organizovanou a zpravidla hranou spolu s dalšími hráči (hra typu play je naopak pojímána jako něco poměrně volného a nezávazného, předpokládá jen existenci rolí a schopnost hrajících si tyto role přebírat).

V souvislosti s edukačním potenciálem efektivity hry dochází v současné době (nejen ve sféře vzdělávání) $\mathrm{k}$ tzv. gamifikaci, tj. užití herních prvků v neherním kontextu. Za tímto trendem stojí jednoduchá úvaha - jestliže hry primárně navržené za účelem zábavy motivují uživatele k intenzivnímu a dlouhotrvajícímu zapojení, měla by jejich implementace do neherních produktů a služeb učinit také tyto produkty a služby zábavnější a vést k obdobné míře (Deterding et al., 2011).

\subsubsection{Prožitek, zážitek, zkušenost}

Názor, že lidé se zkušenostmi jsou úspěšnější než ti, kteří ovládají teorii bez zkušeností, známe již z antiky. V sedmnáctém století pak Locke říkal, že zkušenost musí člověka naučit to, co rozum neumí (Boud, 2000). A konečně Dewey předpokládal, že uprostřed všech nejistot existuje trvalý rámec organického spojení mezi vzděláním a osobní zkušeností. Přestože, jak tvrdí, všechna opravdová výchova a vzdělání přichází skrze zkušenost, ne všechny zážitky jsou opravdu ve stejné míre výchovné (Dewey, 1938).

na myšlence sociálně konstruovaného sociálního světa, tj. plurativní reality vycházející z popisu toho, jak ji vnímají a interpretují sociální aktéři. Více ke konstruktivistické pedagogice např. Kolaříková (2018). 
Výchovu však nelze pokládat za řadu více či méně silných prožitků, podstatnou roli v celém procesu musí hrát reflexe či jiná forma transformace prožitků, potažmo zážitků, ve zkušenosti. V prožitku zvlášt́ vyniká emocionální, tělesná a smyslová stránka činností ( $v$ nejobecnější rovině celého života, bytí), prolíná se zde vědomí aktuálního stavu s víceméně neuvědomělým působením vžitých tradic, konvencí, vzorců chování apod. Německý filozof Dilthey považuje prožitek za první předpoklad sebepoznání i poznání druhého. $V$ prožitku se nám představuje realita, sníž jsme se střetli a zvnitřnili ji. Prožitek není nic daného ani smyšleného. $V$ prožitku se nám objevují nové aspekty života, vidíme obrysy, které jsme nemohli vidět dřive (Pelcová, 2000).

Zážitek potom můžeme chápat jako prožitek uchopený $v$ reflexi, je možné jej vyprávět $v$ podobě príběhu, je možné se ptát, co jsme v dané situaci vnímali, prožívali, co jsme si mysleli (Slavík, 2007). Dodejme, že zkušeností ve výše uvedené posloupnosti můžeme rozumět výtěžek a zhodnocení prožitého, a to jak prostřednictvím reflexe, tak i nevědomě. Nejde tedy o samotný moment akce (jako $v$ prípadě prožitku) ani pamětovou stopu této akce (jako v prípadě zážitku), ale schopnost aplikace zobecněných principů v jiných analogických situacích ${ }^{4}$.

\subsubsection{Diskuse, dialog a reflexe}

Podobně jako nám výše pomohlo odlišit pojmy prožitek, zážitek a zkušenost pro to, abychom mohli lépe postihnout posloupnost výchovy prožitkem, potažmo zkušenostního učení, i v prípadě pojmů dialog, diskuse (potažmo debata) nám může pomoci si tyto pojmy nejprve definovat. Pojmem dialog se snažíme vystihnout situaci, kdy sice dochází k výměně názorů či myšlenek, ale oboustrannou snahou je dojít k pravdivým závěrům, hledat způsoby řešení. Pojem diskuse vnímáme ve významu společné rozpravy na určité téma, to však je třeba odlišit od "debaty“, jejímž cílem není ani tak řešení problému jako spíše obhájení či prosazení názoru jedné ze stran zúčastněných v debatě.

$\checkmark$ dialogu můžeme své poznání a postoje konfrontovat s poznáním a postoji druhých; rozumějme jím společné hledání odpovědí či řešení problému. Na prvním místě by neměly být názory jednotlivců a jejich snaha je prosadit, ale spíše připravenost svoji myšlenku rekonstruovat na základě přicházejících podnětů - at' už z právě prožitých situací, nebo na základě impulsu ostatních účastníků dialogu. Samostatné myšlení tedy hraje podstatnou roli, ale až v interakci v myšlení s druhými. Ve středu dialogu stojí téma či řešený problém a opravdová snaha tento problém řešit. Nejde o soutěž, kdo koho svými argumenty porazí, kdo má pravdu a kdo nikoli, ale o společné hledání. Východiskem k takovému pojetí práce s dialogem jsou pro nás poznatky Vygotského. V jeho sociálně-konstruktivistickém modelu učení je dialog vnímán jako prostředek rozvoje myšlení. Skutečnost, že si z dialogu odnášíme více otázek než odpovědí, je pozitivní - dialog se zvnitřnuje a v mysli pokračuje i poté, co dialog s ostatními už skončil (Lipman, 1996).

Na základě uvedeného můžeme porozumět požadavku, že reflexe, kterou chceme završit právě probíhající edukační proces (např. v podobě hry), má být svou povahou spíše dialogem než debatou založenou na pouhém sdílení zážitků či názorů na průběh aktivity. Obecně reflexí rozumíme „druh sebepozorování, obrácení myšlení na sebe, do vlastního vědomí a pro-žitků“ (Hartl \& Hartlová, 2000 , s. 195). Boud a Walker hovoří o třístupňové reflexi - jedna probíhá před samotnou akcí a zaměřuje se na účastníky, prostředí a dovednosti samotné, další fáze probíhá v průběhu akce a další po akci. Tato třetí podoba je neznámější a pro nás také nejpodstatnější, protože pomáhá zpracovat a tím do jisté míry umocnit zážitky a dále je přetvářet ve zkušenost. Jde tedy o „zpětné ohlédnutí

4 Jednoduchou etymologickou analýzu slova „prožít“ provedl v popisované souvislosti Vážanský, když vycházel z kořene tohoto slova, tedy žít. Uvádí, že předpona pro- dává celému slovu „prožít“ význam "aktivní“ s hodnotou emočního náboje; prožitou skutečností je člověk bohatší o vnitřní statek. Něco, co člověk „prožil“, mělo aktivní, stimulující, vše prostupující a energizující charakter. Prožitek má silně individuální charakter pro vnímání vnitřní i vnější reality. Je nenahraditelný, neopakovatelný, nepřenositelný a velmi obtížně a jen částečně sdělitelný, ale současně je stimulující, aktivující, probouzející vnímání, prohlubující smysl života. Naopak předpona zá- dává celému slovu „zážitek“ význam uceleného, celistvého, přesahujícího (Jirásek, 2005; Vážanský, 1992). 
za aktivitou, programem či určitým časovým obdobím, jehož smyslem je napomoci účastníkům $\checkmark$ procesu racionalizace a zobecnění subjektivních prožitků do podoby v praxi využitelné zkušenosti“ (Svatoš, 2006, s. 66). V pojetí konstruktivistické kognitivní psychologie (resp. didaktiky) bývá reflexe spolu s úvahou považována za určující prvek procesu učení (Franc et al., 2007). Doplňme však, že reflexe nemusí mít vždy podobu rízenou, např. dialogu apod. V určitých př́padech může být dostačující dramaturgicky vhodně sestavený následný program. Plnohodnotnou reflexí může být i připomenutí aktivity formou jiné činnosti - např. promítání fotografii či chvíle strávená o samotě.

\subsection{Metody otevřené práce s dětmi a mládeží}

Pedagogika volného času $v$ českém pojetí se spíše orientuje na organizované volnočasové nabídky (zájmové vzdělávání, školní kluby a družiny, letní tábory) a tím se liší od německé pedagogiky volného času, která se od začátku soustředila spíše na tu část mladé populace, která se neúčastnila institucionalizované mimoškolní výchovy.

V dokumentech MŠMT ČR (Institut dětí a mládeže MŠMT, 2000) nacházíme pro takovou oblast práce s dětmi a mládeží výraz „spontánní činnost“. Ve vyhlášce MŠMT č. 74/2005 Sb., o zájmovém vzdělávání (MŠMT, 2005), jsou jako jedna z možných forem zájmového vzdělávání uvedeny „otevřené nabídky spontánních činností“. Někteři ovšem tento výraz kritizuji (Kaplánek), protože vyvolává dojem, jako by se jednalo o činnost, kterou pedagogové volného času vůbec neovlivňují, ale pouze ji umožňují5.

Chceme-li zapojit děti, které se neúčastní organizované činnosti (neorganizovaná mládež) a nemají moc možností $k$ trávení volného času $v$ bezpečném prostředí, musíme vytvořit takovou nabídku, která bude volně přístupná, bez evidence a bez finančních požadavků (poplatků). To se realizuje např́iklad ve školním klubu anebo $v$ otevřeném klubu ve středisku volného času. Pokud chceme (třeba v návaznosti na školní výuku) strávit čas neformálně, ale současně "pedagogicky“ (s pedagogickým cílem), jako třeba na víkendu, exkurzi, prázdninách, školním výletě nebo projektu (orientační dny), ocitáme se v jiné situaci než ve škole. Pokud hodláme „něco" nabídnut dětem $z$ „nepodnětného prostředí", bude nutné vytvořit takové nabídky, které nikoho neodradí - ani náročností, ani cenou, ani prísnými pravidly. $V$ tom případě vytvoříme nízkoprahové zařízení pro děti a mládež (NZDM). Pro všechny uvedené činnosti můžeme použít výraz otevřená práce $s$ dětmi a mládeží. Tento výraz sice není u nás ještě obvyklý, ale postupně se k nám dostává.

Není snadné najít pedagogické metody pro otevřenou práci s dětmi a mládeží. Chceme zde stručně představit několik takových metod (informal education, pedagogika sociálního prostoru, animace). Tyto metody se vyznačují tím, že nenařizují aktérům, co se bude dít. Vychovatel nepůsobí jako formální autorita, která o všem rozhoduje, realizuje a hodnotí. Tyto metody podporují osobnostní zralost, komunikační a sociální dovednosti, resilienci, enkulturaci a participaci.

\subsubsection{Informal education}

V českém pedagogickém prostředí se setkáváme s pojmem „informální vzdělávání“, příp. „informální výchova“. Tímto výrazem se označuje výchova a vzdělávání, které se realizuje mimo vzdělávací instituci. Ve Velké Británii se však výraz „informal education“ (Dudová et al., 2011) používá také v jiném smyslu, tedy jako výchovný př́stup, při němž pedagog (informal educator) doprovází jednotlivce i skupiny v procesu lidského zrání. Jedná se o metodu, které se uživá v sociálněpedagogické práci s mladými lidmi v nebezpečí sociální exkluze, kteří se ve většině zemí považují za osoby „odsunuté na okraj“ (marginalizovaní), v českém prostředí se někdy označují jako „neorganizovaná mládež“6.

5 Tato forma zájmového vzdělávání se v rámci středisek volného času nazývá „otevřený klub“. Otevřené kluby ale nejsou součástí běžné nabídky těchto zájmových institucí. Pedagog vystupuje v pozici zajištovatele bezpečí (Kaplánek, 2017).

6 Informal education je součástí celoživotního vzdělávání. A proto jejím subjektem není jen mládež, ale celá populace (Jeffs \& Smith, 2019). 
Za tvůrce této metody považujeme britské sociální pedagogy Jeffse a Smitha (2019) ${ }^{7}$. Při vytváření této koncepce pedagogického doprovázení vycházeli z myšlenek pragmatické pedagogiky, ve smyslu zásady learning by doing.

Prostředkem a zčásti i cílem metody informal education je dialog. Prostřednictvím dialogu se ze zážitků vytváří zkušenost. Na základě této zkušenosti si mladý člověk rozšiřuje své pohledy na život a prostředí, $v$ němž žije (mikroprostředí i makroprostředí). Znamená to, že prostřednictvím dialogu s informálním pedagogem se mladí lidé učí dialogu mezi sebou, a tak vytváří malou skupinu s úzkými meziosobními vztahy (comunity). Při dialogu s informálním pedagogem se mladí lidé učí reflektovat to, co prožili.

Informal education se považuje za spontánní proces, v němž jsou hlavními aktéry sami mladí lidé. Pedagogové jsou zde pouze $v$ roli průvodců, kteří jim pomáhají, aby lépe porozuměli svým zkušenostem a objevili jejich význam. V kontrastu $\mathrm{k}$ formálnímu vzdělávání se rozhovory a aktivity mohou konat kdekoliv a kdykoliv. Jde o vytváření př́ležitostí pro mladé lidi, aby se zamýšleli nad svými zkušenostmi, a tak si kladli srozumitelné otázky týkající se jejich života a prostředí.

Informal education se soustředí na schopnost konverzace a právě ta je klíčová pro budování funkčních skupin. Vzájemné pochopení hodnot a chování je podmínkou pro participaci a demokracii ve skupině i v společnosti (Sennett, 2012). Mezi hodnoty, s kterými pracují informální pedagogové, patří: pracovat pro blaho všech, respektovat jedinečnost a důstojnost každého člověka, spravedlnost, svoboda a participace při řešení otázek, které ovlivňuji jejich život, i samotný dialog (Jeffs \& Smith, 2019).

Čím jsou informální pedagogové specifičtí? - Některé situace vyžadují hlubší porozumění nebo širší škálu schopností a dovedností, než se nám dostává v běžném životě. Skrze reflexe a školení se informální pedagogové stávají specialisty na doprovázení v dialogu, tedy facilitátory skupin či rozhovorů s jednotlivci. Mezi jejich schopnosti patř́ umístit dialog do centra jejich činnosti, umí pracovat v širokém spektru různých prostředí - od škol až po nákupní centra, hledají a vytvářejí či prohlubují situace, $v$ nichž se mohou lidé spontánně učit, bádat a rozšiřovat své zkušenosti, a nakonec učinit i změny ve svém životě.

Informální pedagogové nezapomínají na budování spravedlivých a demokratických vztahů a organizací, které umožní lidem participovat ve společnosti. Pracují prostřednictvím skupinové práce, neformálního rozhovoru, nabídkou rozmanitých aktivit (Jeffs \& Smith, 2019) a individuální práce s člověkem. Umí pracovat slidmi všech věkových skupin, kultur a náboženství. Podněcují k rozvoji zájmu, gramotnosti, vzdělávání a komunitního rozvoje.

\subsubsection{Pedagogika sociálního prostoru}

Pro pedagogiku sociálního prostoru ${ }^{9}$ je právě „prostor“ základním předpokladem a centrem sociálních vztahů, v kterých děti a mladí lidé vyrůstají a rozvíjejí se (Deinet, 2007). Pedagogika sociálního prostoru by měla odpovídat na otázky: Jak pomoci mladým lidem formovat svůj životní prostor, který je podmínkou pro úspěšné zvládnutí života? Jak jim pomoci k prevzetí odpovědnosti za vlastní činy? Jak sladit vlastní zájmy a potřeby se zájmy a potřebami ostatních? Jak pomoci k naplnění potřeby

7 Anglické informal education připodobňují ke skotské komunitní práci, k německé sociální pedagogice a k francouzské animaci (Jeffs \& Smith, 2019). Výraz „informal education“ používáme v orginále záměrně, jeho překlad by mohl vést k nesprávnému propojení s některou z kategorií tzv. účelové učební činnosti (formální, neformální, informální učení).

8 Rodiče či prátelé jsou jakýmisi neformálními průvodci, ale tito profesionálové jsou schopni aplikovat poznatky a způsoby práce, které pomohou člověku dostat se k významným otázkám vlastního života, tedy najít odvahu ptát se.

9 V německé literatuře orientované na práci s neorganizovanou mládeží se koncem osmdesátých let 20. století setkáváme s pojmem Sozialräumlich orientierte Kinder- und Jugendarbeit („práce s mládeží orientovaná na sociální prostor") nebo také s pojmem Sozialräumliche Jugendarbeit, ve volném překladu s pedagogikou sociálního prostoru. $V$ dalších letech se od samotného pojmu pedagogika ustoupilo a tento koncept byl dále rozvíjen jako sozialräumlichen Konzeptentwicklung (Deinet \& Krisch, 2002). 
„mít vlastní prostor"? Jak dát príležitost mladým lidem podílet se na rozhodnutí v komunitě? Východiskem pro toto pojetí se stala myšlenka „přivlastnění“ (Aneignung) ${ }^{10}$.

Pod pojmem sociální prostor rozumíme sociálně konstruovaný prostor, tedy životní prostor, sociální prostředí, životní prostředí, kde probíhají procesy sociálního rozvoje. Tento prostor nemusí mít své geografické hranice a vymezení, nejde ani o čtvrt' či část obce. Sociální prostor zahrnuje veškerá prostředí, včetně prostoru virtuálního. Jedná se prostor, který mohou mladí lidé využívat bez ohledu na svoji př́slušnost a kde mají př́ležitost setkat se s vrstevníky, společně trávit volný čas a aktivně se účastnit činností dle svých vlastních schopností čí převzít iniciativu, např. prostřednictvím projektů a nabídek aktivit.

Cílem pedagogiky sociálního prostoru je povzbudit a podpořit děti a mládež v rozvoji sociálních vztahů a přivlastňování sociálního prostoru. Přivlastnění sociálního prostoru je chápáno jako vývojový úkol dětí a mladých lidí, jehož prostřednictvím se mladiství setkávají se sociálními hodnotami a normami, mohou rozvíjet své schopnosti a kompetence. Vypořádání se s prostorově zprostředkovaným prostředím založeným na věku, pohlaví a životní situaci umožňuje vzdělávací procesy (Deinet \& Reutlinger, 2005).

V tomto prostředí získávají mladí lidé prostor, kde mohou společně pobývat, něco zažít i sebe zažít, vyzkoušet a učit se sociálním a komunikačním dovednostem. $K$ podpoře vývojových procesů a rozvoji mladých lidí tu docházi i za přispění vrstevníků. Takový prostor otevírá možnost učení v různých oblastech života (sociální učení). Předpokladem je svoboda a volnost, také vzájemný respekt, zbavení se tlaku od primárních socializačních orgánů a institucí. Vyzkoušet si nové a realizovat své nápady souvisí také srelaxací a regenerací ismožností zažívat a prohlubovat mezilidské vztahy. Sociální přivlastnění určitého prostředí umožňuje získání pozitivních participativních zkušeností, podobně jako je tomu u komunitní práce.

"Sociálně prostorová práce s mládeži“ umožnuje zprostředkovávat potřeby mladých. Cílem je porozumět životnímu prostředí adolescentů v kontextu jejich sociálního prostoru. Je prostředkem k propojování různých kultur např́č generacemi a obecně posiluje soudržnost komunity. Využití socioprostorové metody umožnuje vnímat a dokumentovat procesy v komunitě ve strukturované a kontinuální formě. Intenzivní dialog a zkoumání pohledu dětí a dospívajících na jejich životní prostory umožňuje rozvíjet a prosazovat vhodné možnosti přivlastňování jak v práci s mládeží, tak ve veřejném prostoru. Sociálně prostorová práce s mládeží umožňuje mladým lidem podílet se na rozhodování o svém prostoru a naplnění času a jeho využití nebo i na změně veřejného prostoru, a tím podporuje pohodu, spokojenost a identifikaci s komunitou.

\subsubsection{Animace}

Animace - v pedagogickém smyslu - nám ze svého základu nabízí jiné perspektivy ${ }^{11}$. Pokud vycházíme z původního významu slova anima, chápeme animaci jako oduševnění, přičemž v antické tradici byl "dech" (řec. pneuma = dech i duch) nejen projevem, ale i pramenem života. Animace by tedy neměla být pouze oživením ( $\mathrm{k}$ pohybu), ale oživením či probuzením $\mathrm{k}$ (novému) životu, tedy k nové kvalitě života.

Francouzský pedagog Limbos hovoří o animaci jako o vtisknutí duše. Zdůrazňuje význam "ducha“ skupiny či tř́dy. Je-li ve skupině dobrá atmosféra a klima, mohou se její členové cítit velmi dobře. Ale pokud tam chybí duch, tedy určitý směr (hodnotové priority, styl jednání), chybí tam něco velmi podstatného (Limbos, 1977). Podle polského pedagoga Kargula proces animace umožnuje změny

10 Koncepce přivlastnění (Aneignungskonzept) počítá s mladým člověkem jako aktivním subjektem ve svém vlastním sociálním prostoru. Tento přístup má samožrejmě politické obsahy a ambice.

11 Výraz animace pronikl do našeho pojmového diskurzu z románských jazyků a má svůj etymologický původ v latinském slovu „anima“ (duše). Sloveso animovat znamená oduševňovat, oživovat, probouzet. Každý z nás si asi představí animovaný film, kde animátor „oživuje“ filmové postavičky a někdy je přímo „postrkuje“ nebo jen mechanicky posouvá k pohybu. 
osobnosti, které se už během procesu animace projeví. Kargul (1995) shrnuje změny způsobené animací v následující Tabulce 2.

Tabulka 2

Možnosti změny vlastností osobnosti v procesu animace

\begin{tabular}{|c|c|c|c|c|c|c|}
\hline \multicolumn{7}{|c|}{ Stav a změny vlastností osobnosti } \\
\hline Stav & Pasivita & Vnímavost & $\begin{array}{l}\text { Zaměření na } \\
\text { sebe }\end{array}$ & Izolace & $\begin{array}{l}\text { Schematičnost } \\
\text { akcí }\end{array}$ & $\begin{array}{l}\text { Stereotypní } \\
\text { myšlení }\end{array}$ \\
\hline Změna & Aktivita & Kreativita & $\begin{array}{l}\text { Zaměření na } \\
\text { skupinu }\end{array}$ & Družnost & $\begin{array}{l}\text { Inovativnost } \\
\text { akcí }\end{array}$ & $\begin{array}{l}\text { Kreativní } \\
\text { myšlení }\end{array}$ \\
\hline
\end{tabular}

Ke změnám dochází v důsledku nově nabytých zkušeností o sobě i druhých lidech, stejně jako o jevech a problémech životního a sociálního prostředí. Dále také rozvojem dovedností a schopností využít a uplatnit nově získané znalosti a kompetence. Změny se týkají oblasti myšlení, přístupu k sociálním problémům, hierarchie hodnot, kde začínají nabývat na významu hodnoty jako solidarita, pomoc druhým i angažovanost a zájem o svět kolem nás.

Můžeme hovořit o různých modelech animace (kulturní animace, sociálně-kulturní animace, divadelní animace, motivace $k$ zábavě $v$ turistických střediscích). Všechny tyto modely pracují s prvkem probuzení $k$ aktivitě, dění $v$ životě člověka. Metody animace jsou specifické tím, že jedincům a skupinám usnadňují přístup $\mathrm{k}$ tvořivému životu. Různé animační metody obsahují stejné prvky, ale každá má trochu jiné priority. Například sociálně-kulturní animace klade důraz na umožnění sociální participace, kulturní animace na skupinu jako výchovné prostředí.

Za kolébku animace můžeme považovat Francii, kde se animace od 60. let minulého století etabluje jako forma komunitní práce (I'animation social-culturel) s důrazem na osobu animátora, tedy člověka, který objevuje, probouzí a rozvíjí ve členech komunity jejich skrytý potenciál.

Cílem sociálně-kulturní animace je angažovanost (iniciativa) člověka ve své kultuře a společnosti po stránce sociální, politické či společenské. Důvodem sociálně-kulturních iniciativ byla vnitřní nejednota komunit, často vyloučených, a jejich pasivita. Podstatou sociálněkulturního pojetí animace je především podpora procesů sociální participace a posílení zapojení širokých vrstev obyvatelstva do společenského a kulturního života ${ }^{12}$. Zaměřuje se na motivaci, podporu iniciativy a aktivní účast na životě komunity (Dudová, 2018).

V práci s mládeží může pedagogický a sociální pracovník použít sociálněkulturní animaci k tomu, aby mladým lidem pomohl verbalizovat názory a angažovat se pro zvolený politický směr. Participace na životě společnosti je totiž současně cílem i prostředkem sociálněkulturní animace. $V$ mládí člověk touží po změnách a má vnitřní motivaci se pro ně angažovat. Mnohdy je tento potenciál zatlačen do pozadí dospělými (společností) anebo zneužit k dosahování cizích cílů (ideologie). Proto sociálněkulturní animace vede mladé lidi k tomu, aby uskutečňovali to, co je pro ně důležité, a včas rozeznali nebezpečí zneužití (Gillet, 1998).

Myšlenka animace se $v$ 70. letech rozšírila po celé západní Evropě. V Německu tuto myšlenku převzal Opaschowski, jeden ze zakladatelů pedagogiky volného času, a začal ji propagovat jako metodu pedagogiky volného času. Nazval ji "freizeitkulturelle Animation" (animace volnočasové kultury). Opaschowski viděl $v$ animaci možnost, jak nabízet konkrétní principy pro výchovnou práci v rámci otevřené práce s mládeží (Offene Jugendarbeit) ve volném čase. Mezi základní metody pedagogiky volného času proto zařadil tzv. komunikativní animaci (Opaschowski, 1976).

12 Animátoři (původně aktivisté z řad levicové inteligence) chtěli dosáhnout propojenosti mezi běžnými občany; snažili se je podněcovat k vzájemné solidaritě, komunikaci a sdílení s ostatními. Tito původní animátoři byli vedeni myšlenkami lidských práv a svobod, včetně práva na informovanost i na změnu politických poměrů (Kaplánek, 2013). 
Podobně jako propagátoři animace ve Francii považoval v té době (70. a 80. léta) také Opaschowski animaci za metodu kulturni práce s lidovými vrstvami. Jedna jeho kniha nese název Einführung in die freizeitkulturelle Breitenarbeit, což zřetelně dokládá jeho zaměření na poskytnutí možnosti rozvoje širokým masám společnosti (Opaschowski, 1979).

Opaschowski rozvíjel freizeitkulturelle Animation jako př́spěvek k rozvoji volnočasové kultury jedince i celé společnosti. Z hlediska individuálního to znamená, že cílem takto pojaté animace bylo uschopnit jedince $\mathrm{k}$ zralému způsobu využití volného času jako integrální součásti života (Kaplánek, 2011). Animaci Opaschowski definuje jako nedirektivní motivaci, podněcování a podporu, která umožnuje aktivitu, uvolňuje kreativitu, podporuje vytvoření skupiny a usnadňuje účast na kulturním životě. Své principy pedagogiky volného času ${ }^{13}$ původně nazýval "principy animace“. Později je přejmenoval na principy pedagogiky volného času. $Z$ této změny lze usuzovat, že tyto principy jsou platné $i$ tehdy, když je nespojujeme s pojmem animace.

Ze stejného zdroje - francouzské sociálně-kulturní animace - vycházel také italský psycholog Pollo, který se pokusil použít myšlenku animace $v$ salesiánském výchovném prostředí. Protože v jeho pojetí byla cílem animace enkulturace, nazval výchovný směr animace l'animazione culturale (kulturní animace). Kulturní animaci Pollo prezentuje jako způsob života a postoj vedený láskou k životu, která se ukazuje ve víře v možnosti rozvoje každého člověka i celé společnosti ${ }^{14}$.

Pro Polla je kulturní animace metodou, která umožnuje výchovně doprovázet skupiny mladých lidí na cestě $k$ dospělosti ${ }^{15}$. Tato cesta má jasnou vizi, pro niž Pollo používá pojem „životní projekt“ (progetto della vita); jedná se o určitou představu o vlastní budoucnosti (Kaplánek, 2013). Pro Polla je důležité chápat lidský život v kontextu plynutí času. Opírá se přitom o myšlení Frasera, který se věnuje problematice temporality v lidském životě ${ }^{16}$. Mladý člověk by měl dospět do stavu, kdy bude vědět, odkud vychází a kam směřuje (Pollo, 2005).

\section{Volnočasová kompetence - a jak jí dosáhnout?}

Abychom mohli dosáhnout „volnočasové kompetence“, musíme tento obecný pedagogický cíl rozdělit na dílčí cíle, jejichž dosažením se různými cestami („metodami“) k tomuto cíli budeme postupně přibližovat. Přitom můžeme vycházet ze tří koncepcí výchovy k volnému času:

1. První koncepce výchovy $\mathrm{k}$ volnému času chápe volnočasovou kompetenci jako komplex sociálních, komunikativních a praktických dovedností (leisure skills), které jsou potřebné k tomu, aby účastník volnočasový aktivit (včetně účastníka s handicapem) mohl úspěšně a s uspokojením realizovat ty volnočasové aktivity, které si vybere. Toto pojetí je nejbližší pojetí většiny pedagogů volného času v ČR. Také na některých univerzitách, především v USA, najdeme studijní obory,

13 Dostupnost, otevřenost, přitažlivost, samostatné rozvržení času, dobrovolnost, nenucenost, možnost výběru, možnost svobodného rozhodnutí, možnost být iniciativní (Opaschowski, 1976).

14 Pollo (2005) definuje čtyři výchovné pilíre kulturní animace. Přitom klade důraz na osobnostní nároky na pedagogického pracovníka (animátora) - lidskou zralost a odbornou způsobilost. Animátor v Pollově pojetí usměrňuje, vnáší nadšení a motivaci. Je součástí skupiny v roli jakéhosi garanta hodnot. Je to právě animátor, kdo je nositelem hodnot (jedná se o tradiční hodnoty kultury, do nichž mladá generace vrůstá, ale současně je sama přetváŕí). Animátor sám tyto hodnoty reprezentuje a současně pomáhá skupině, aby si dokázala formulovat své vlastní hodnoty, postoje, zájmy a potřeby. Animátor ztělesňuje základní myšlenku animace - víru v dobré jádro ukryté v každém jedinci, které má on jako vychovatel pomoci objevovat a rozvíjet (Kaplánek, 2013).

15 Kulturní animace má své metodické postupy: Pollo se snaží jasně ukázat cestu (jak to dělat). Např́iklad v slovenském salesiánském prostředí formulovali program s názvem Cesty zrenia, $v$ němž je popsán metodický postup (itinerář) práce s dětmi a mládeží v duchu salesiánské pedagogiky (Dudová et al., 2014).

16 Temporalita jako určenost časem je př́tomností, v níž je obsažená podstatná minulost a také v každém okamžiku rozvrh či plán pro budoucnost. V českém prostředí se socialtemporalitě a nootemporalitě $v$ chápání Frasera a Polla více věnuje Kaplánek (2011). 
které připravují odborníky v této oblasti ${ }^{17}$. Pokud budeme sledovat tuto koncepci, můžeme se spolehlivě opřít o teorii a zkušenosti z praxe našeho zájmového vzdělávání a dětských organizací.

2. Druhá koncepce je založena na přesvědčení, že $k$ dosažení volnočasové kompetence nestačí pouze sociální, komunikativní a praktické dovednosti. Proto např́klad National Rekreation and Park Association (NRPA) zdůrazňuje dílčí kognitivní cíle, které jsou předpokladem volnočasové kompetence. Podobně uvažuje Munusturlar, který se zabývá výchovou k volnému času v tureckých školách. Jak NRPA, tak turecká leisure education ve školách považují za klíčové, aby si děti uvědomily význam volného času, a to jak v rovině individuální, tak v rovině sociální, politické a ekologické. Po stránce individuální jde také o hlubší uvědomění vlastní motivace k volnočasovým aktivitám (Munusturlar \& Bayrak, 2017; Zeyen et al., 1997).

3. Třetí koncepce chápe výchovu $\mathrm{k}$ volnočasové kompetenci jako výchovu ke svobodě. $\mathrm{V}$ tomto prípadě je volnočasově zralý (kompetentní) člověk takový člověk, který umí svobodně nakládat se svým volným časem v kontextu celého svého života a jeho smyslu. Toto pojetí se opírá především o názory německého pedagoga volného času Opaschowského (1996), ale také o některé autory amerického kontinentu, jako je např. Hutchinson (2014).

Tito autoři považují za dílčí cíle výchovy k volnému času:

- Rozvoj schopnosti „obrátit sám k sobě“ (do sebe), a tak prožívat leisure (scholé) jako „postoj přijímajícího vnímání, nazírajícího kontemplativního ponoření se do jsoucna" (Pieper, 2007, s. 86-87).

- Věnovat čas a energii formulaci vlastní životní vize a konkrétních životních cílů (Hutchinson, 2014).

Pro naše uvažování jsou inspirující dílčí kompetence, které uvádí Opaschowski, protože se vztahují prímo na volný čas, ačkoliv to, co se při učení těmto kompetencím děti naučí, využijí nejen ve svém volném čase, ale stane se to pro ně významným faktorem při utváření celého jejich života. Opaschowski (1976) uvádí tyto dílčí kompetence, kterých by měl člověk dosáhnout, aby se stal volnočasově zralým:

- $\quad$ odhalovat tendenci ke zvyšování konzumu v rámci volného času;

- získat obranné mechanismy proti vlivům omezujícím svobodu rozhodování;

- prijijmout volný čas jako prostor k vědomému rozšiření zkušeností a zážitků;

- príijmout volný čas jako prostor, $v$ němž můžeme rozvinout společenské alternativy a sami si určovat životní podmínky;

- využívat volný čas ke změně (vědomému utváření) postojů, vnímání a jednání;

- chápat volný čas jako možnost změny vlastní osoby a jejího okolí.

Jak je vidět, Opaschowski $(1976$, s. 119-121) formuluje skrze tyto kompetence cíle kognitivní a afektivní (postojové). $K$ dosažení těchto cílů (kompetencí) by měl pedagog rozvíjet tyto schopnosti dětí:

- kritické myšlení, které odhaluje tendence ke zvyšování konzumu ve volném čase a k manipulaci, např. ze strany médií;

- $\quad$ reflexe a sebereflexe, včetně uvažování o cíli vlastního života, o volném čase a jeho využití ( $k$ vlastnímu růstu) a o sociálních vazbách;

- obrana proti vlivům omezujícím svobodu rozhodování (resilience);

- inovativní potenciál (možnosti k rozvoji sociálních alternativ a jiných změn vlastního života i svého okolí).

17 Informace o studijních oborech a kurzech online: Lifetime Fitness and Leisure Activities (n.d.), Department of Exercise, Health, and Sport Sciences (n.d.), Academic Catalog 2021-2022 (Slippery Rock University, n.d.), Lifetime Leisure Skills (IOWA Recreational Services, n.d.). 


\section{Zhodnocení edukačních metod z hlediska jejich vhodnosti ve výchově zaměřené na volnočasovou kompetenci}

Úkolem autorů tohoto příspěvku v rámci projektu Prožívání volného času dětí staršího školního věku jako výzva pro pedagogiku (TA ČR Starfos, n.d.) je vybrat a rozvinout edukační metody, které jsou vhodné pro výchovu $\mathrm{k}$ volnému času (education for leisure), jejímž cílem je volnočasová kompetence. Předpokladem výběru, rozvíjení a prípadné adaptace edukačních metod je jejich posouzení z hlediska přiměřenosti a vhodnosti pro dosažení tohoto cíle. Abychom si nejprve udělali představu o tom, které metody jsou již voblasti organizovaného volného času (konkrétně v oblasti zájmového vzdělávání ve školních družinách a klubech) obvykle uplatňovány, nabízíme stručné představení výzkumné sondy, kterou v záŕí 2020 realizoval jeden z autorů tohoto textu.

\subsection{Průzkum didaktických metod v zájmovém vzdělávání}

Konkrétně se jednalo o dotazníkový výzkum zacílený na zmapování metod využívaných v práci vychovatelů ve školní družině a na způsoby práce s metodou hry ve stejném prostředí. Pro výzkum byla použita výše popsaná baterie výukových metod dle Maňáka (srov. Tabulka 1) terminologicky upravená pro potřeby výše uvedených zařizení ${ }^{18}$.

\subsubsection{Výzkumný soubor}

Žádost o vyplnění dotazníku jsme zaslali 4155 ředitelům základních škol v ČR s prosbou o sdílení mezi pracovníky školní družiny a školního klubu. Takto jsme získali 582 plnohodnotně vyplněných dotazníků, ve kterých bylo zastoupeno 13 mužů a 569 žen s následujícími relevantními charakteristikami. $S$ ohledem na místo bydliště byla nejčetnější kategorie respondentů z vesnic -211, tj. 36,2 \%. Rovnoměrně pak byli zastoupeni respondenti z velkých měst (nad 100 tis. obyvatel), menších měst (10-50 tis. obyvatel) a malých měst (do 10 tis. obyvatel) - každá z těchto skupin respondentů byla zastoupena necelými $20 \%$. Podobně tomu bylo i z hlediska velikosti obce, kde se nachází zařízení, v němž respondenti pracují. 441 respondentů (což je více než 75 \% výzkumného souboru) pracovalo se skupinou o velikosti 21-30 osob, dalších 20 \% respondentů pak se skupinou menší než 20 osob. Průměrný věk respondentů byl 45,2 let. Nečetnější skupinou zastoupenou v souboru však byli respondenti ve věku 46-55 let, kteří tvořili 37 \% všech respondentů.

\subsection{Výsledky šetření}

Z baterie nabízených metod (Příloha 1) respondenti nejčastěji uváděli manuální činnosti (88\% respondentů je zařazuje pravidelně, a to velmi často nebo často), pohybové činnosti ( $93,5 \%$ je zařazuje pravidelně, a to velmi často) a hra $(95,4 \%$ respondentů ji zařazuje pravidelně, a to také většinou velmi často). Méně často je užíván výklad a dramatizace, kterou většina respondentů používá spíše nepravidelně. Užití dramatizace také rozděluje jednotlivé skupiny respondentů (viz dále).

Jak se liší odpovědi respondentů dle věku? Krabicové grafy 1 až 3 umožňují porovnání na základě mediánu odpovědí respondentů na pětistupňové škále od 0 do 4 ( $\mathrm{tj}$. vůbec nevyužívám danou metodu - danou metodu používám velmi často). Věkové kategorie jsou následující: do 25 let (1), 26-35 let (2), 36-45 (3), 46-55 (4) a více než 55 let (5). Vidíme na nich trochu překvapivě, že mladší respondenti méně často používají dramatizaci ${ }^{19}$, práci s knihou a texty a také předvádění či jinou podobu metody názorné demonstrace. Tyto výsledky jsme ověřovali pomocí statistických testů, konkrétně Kruskal-Wallisova testu. Na hladině významnosti $p<0,05$ jsme pro uvedené metody mohli zamítnout

18 Náhled výzkumného nástroje (dotazníku Metody výchovy ve volném čase) je čtenářum $\mathrm{k}$ dispozici (Google Forms, n.d.).

19 Metoda dramatizace vykazuje specifické výsledky, i pokud výzkumný vzorek respondentů rozdělíme dle jiných kritérií; je třeba připustit skutečnost, že došlo k rozdílné interpretaci významu pojmu "dramatizace“ u jednotlivých respondentů. 
nulovou hypotézu o tom, že medián zastoupení odpovědí respondentů na škále se s ohledem na jejich věk nemění, tedy je shodný mezi všemi skupinami.

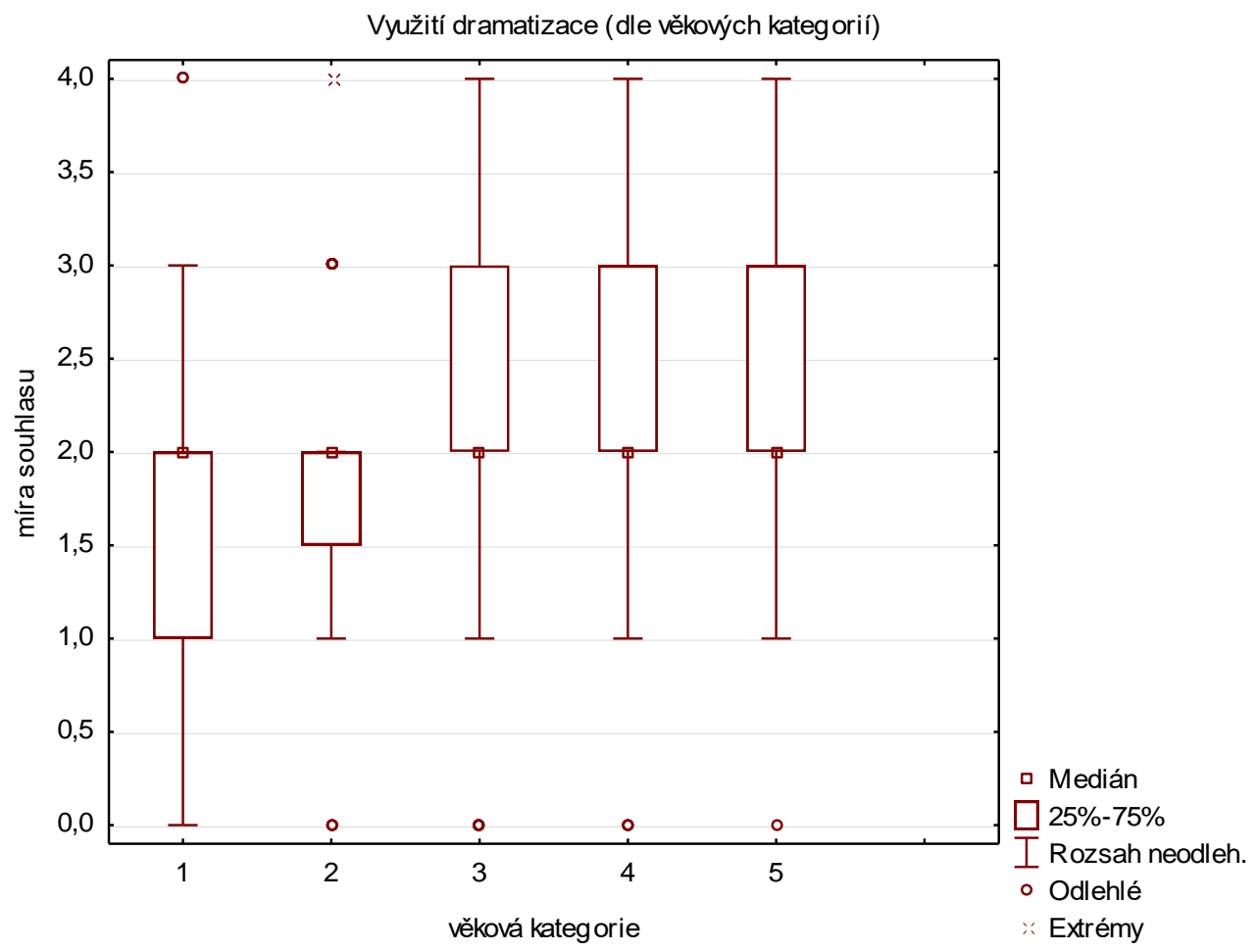

Graf 1 Využití metody dramatizace v závislosti na věku respondentů

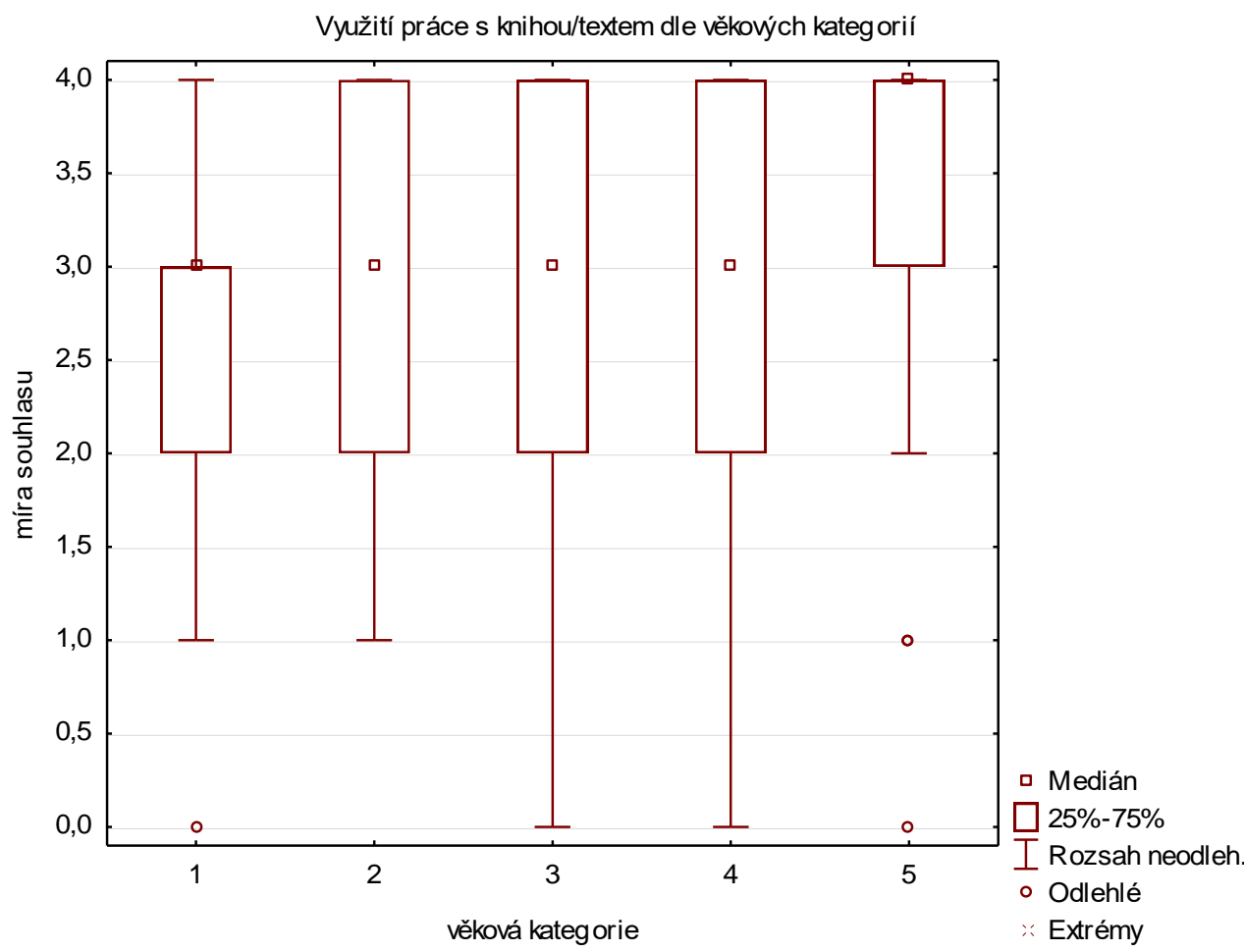

Graf 2 Využití metody práce s knihou/textem v závislosti na věku respondentů 


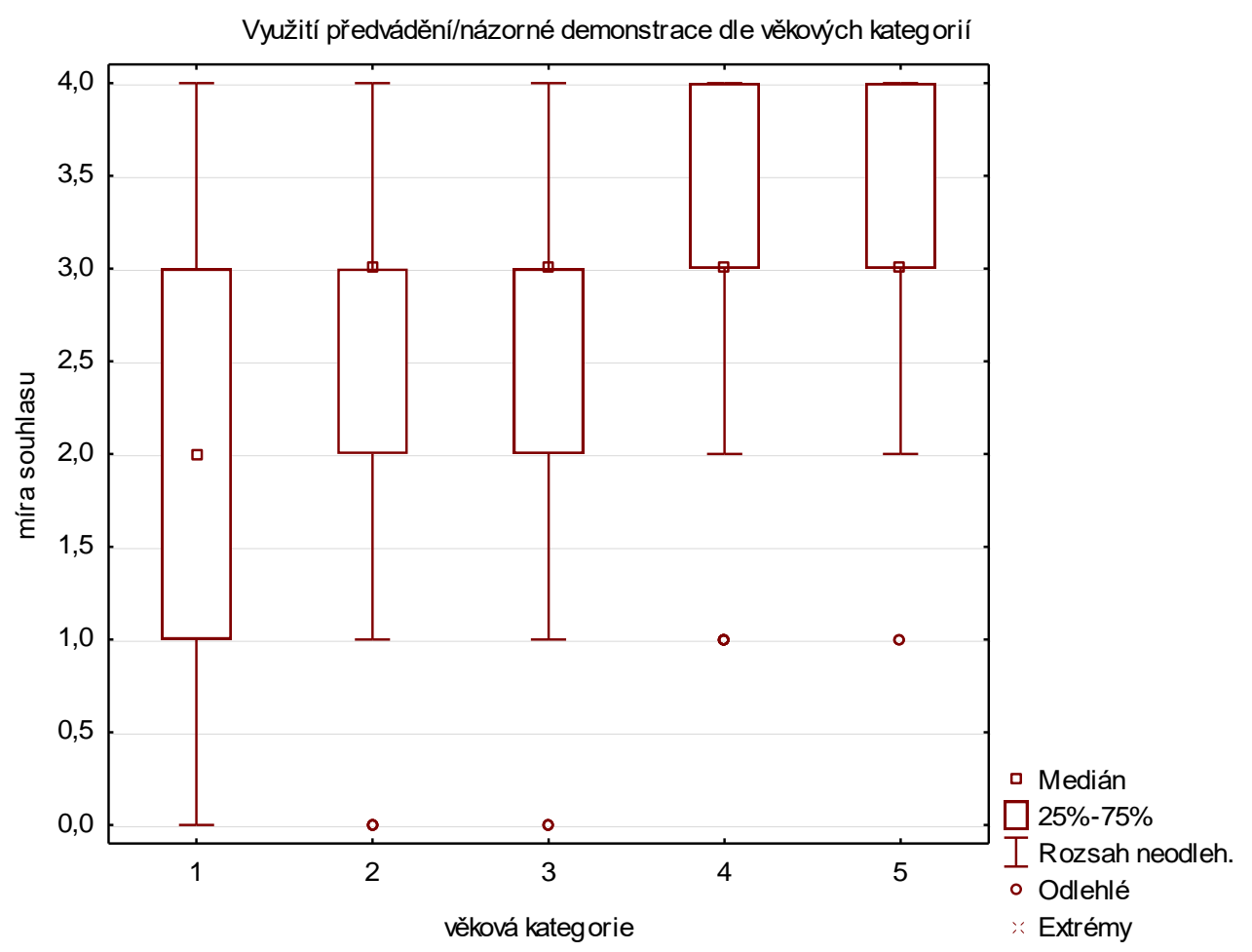

Graf 3 Využití metody předvádění/názorné demonstrace v závislosti na věku respondentů

\subsection{Interpretace šetření}

Z uvedených výsledků je patrné, že ve školních družinách, potažmo ve školních klubech, kde jsme šetření provedli, převládá tradiční uplatňování metod, které odpovídá léty zažité programové skladbě činností v těchto zařízeních. Dominují manuální činnosti, zejména jde o činnosti výtvarné (kreslení a malování, vytváření koláží apod.). Přestože jde o činnosti, které mohou rozvíjet hned několik klíčových kompetencí (kromě pracovní, také kompetenci k řešení problémů, kompetenci k učení a snad i další), můžeme vypozorovat spíše latentní cíl v podobě připomínání lidových zvyků a obyčejů a opakování vývojově částečně poddimenzovaných znalostí o přírodě, ročních obdobích apod.

Pohybové činnosti mají často charakter neř́zené, tedy spontánní činnosti na hřišti, popř. během vycházky. V případě rízených činností jde o opakování známých, ale oblíbených pohybových her. Podobně je tomu i u všech ostatních her; $z$ dalších položek $v$ dotazníku zaměřených na práci s hrou (na které se $v$ této studii nezaměřujeme) je totiž patrné, že vychovatelé projevují jen malou kreativitu při modifikaci známých a osvědčených her (obměna legendy, využití netradičních rekvizit apod.), takřka nevyužívají plného potenciálu reflexe v závěru herní aktivity.

Pokud jsme v první kapitole představili tři skupiny metodických př́stupů, s nimiž můžeme pracovat (metody převzaté ze školské didaktiky, inovativní metody vycházející z konstruktivistického př́stupu a metody odpovídající na potřeby tzv. nedirektivní výchovy, tedy výchovy a doprovázení dospívajících $v$ rámci otevřené práce), vidíme, že jsou to především didaktické metody odvozené od metod školské didaktiky, které v uvedených typech zařízení dominují. Pro optimální rozvoj volnočasové kompetence považujeme za důležité tyto metody kombinovat s metodami ostatních zmíněných přístupů.

\subsubsection{Vhodnost edukačních metod převzatých ze školské didaktiky}

V odstavci 2.1 jsme se pokusili přizpůsobit přehled výukových metod stanovených Maňákem potřebám pedagogů volného času. Tím jsme se dostali k několika metodám, jako je výklad nebo popis, vyprávění, diskuse, práce s textem, názorná demonstrace, realizace manuálních, pohybových a expresivních aktivit. 
V organizovaných zájmových aktivitách dětí staršího školního věku se setkáváme především se zájmovými útvary, $v$ nichž se realizuje pravidelné zájmové vzdělávání, jehož primárním cílem většinou je, aby dítě dosáhlo konkrétních kompetencí, díky nimž může úspěšně realizovat zvolenou zájmovou činnost (leisure skills).

Některé z výše uvedených metod - výklad, vyprávění, práce s textem, diskuse - slouží v neformálním vzdělávání, podobně jako ve škole, $k$ dosahování dílčích kognitivních cílů, které jsou pro výchovu zaměřenou na volnočasovou kompetenci velmi důležité. Nicméně se ukazuje, že tyto metody nerozvíjejí dostatečně samostatné kritické myšlení a schopnost reflexe a sebereflexe, což jsou základní předpoklady $\mathrm{k}$ dosažení volnočasové kompetence. Budeme-li chtít zařadit „výchovu k volnému“ času mezi témata osobnostně-sociální výchovy v rámci formálního vzdělávání, je nasnadě, že budeme použivat také těchto metod, ovšem s vědomím jejich omezenosti.

\subsubsection{Edukační metody $\mathrm{z}$ hlediska konstruktivistické pedagogiky}

Pokud se podíváme na vývoj pedagogických směrů v posledním století, vidíme, že didaktické metody - a tedy ani metody pedagogiky volného času - nemůžeme jen tak jednoduše dělit na tradiční a inovativní nebo konzervativní a progresivní. Jak bylo naznačeno v první kapitole, mohou být stejné metodické postupy naplněny jiným duchem.

Tuto zkušenost můžeme demonstrovat právě na vybraných metodách jako diskuse nebo hra, které se odedávna používají v edukačním procesu, a přece mohou nabývat v různém kontextu zcela jiného charakteru, a tedy mohou být - na základě různých přístupů - pro dosažení „,našeho cíle“ - volnočasové kompetence - více nebo méně vhodné. Pokud uvažujeme o diskusi jenom jako o řízené "výměně názorů“, musí učitel (pedagog volného času) diskusi poměrně silně regulovat, aby dosáhl cíle. Pokud ovšem vnímáme diskusi z hlediska konstruktivistické pedagogiky, probíhají při diskusi zcela jiné skupinové procesy, takže jsou účastníci mnohem více zataženi do hledání odpovědí. Tím se učí na jedné straně samostatné reflexi, ale na druhé straně i formulaci svých názorů, což může velmi přispět $k$ dílčím kognitivním kompetencím potřebným pro získání volnočasové zralosti.

Podobně je tomu při hře. Pokud vnímáme hru pouze jako edukační prostředek, zůstaneme obyčejně v zajetí reduktivního př́stupu ke hře, kdy ji vnímáme pouze jako nástroj k efektivnímu dosažení edukačního cíle. $Z$ hlediska výchovy k volnočasové zralosti dáváme přednost restitutivnímu pojetí hry, kdy jde především o hraní samotné, které patří k antropologickým konstantám kulturní historie. $Z$ konstruktivistického hlediska jde opět o to, co vytvářejí (konstruují) sami účastníci hry, v našem prípadě děti staršího školního věku.

Podstata konstruktivistického př́stupu ale není v jednotlivých metodických postupech, ale spiše v principech, z nichž jsme vybrali dva, které mají význam i pro naše téma. Jedná se o princip reflektovaného zážitku a o princip dialogu. Jak vyplývá z 3 . kapitoly, cesta k volnočasové kompetenci vede i přes reflexi - uvědomění si a pochopení vlastního života, prostředí i samotného volného času a jeho významu. Pro uvědomění si a pochopení života a jeho hodnot je nesmírně důležité, abychom si uměli naslouchat a současně formulovat vlastní postoje. Proto považujeme princip dialogu za nosný princip výchovy k volnému času.

\subsubsection{Přístupy používané $v$ otevřené práci $s$ dětmi, mládeží a jejich vhodnost při výchově $k$ volnočasové kompetenci}

Přístupy otevřené práce $s$ dětmi a mládeží mají řadu společných prvků. Jedním z těchto prvků je postava animátora, resp. informálního pedagoga. Animátor je důležitým činitelem procesu, který pracuje se skupinou na základě osobního vztahu ke všem členům skupiny. Přitom věří v sílu - skrytý potenciál skupiny i jejích jednotlivých členů, pomáhá ho objevovat, probouzet, realizovat a rozvíjet.

Hlavním prostředkem práce animátora je komunikace mezi ním a skupinou. Animátor je profesionálem v porozumění skupinovým procesủm, podporuje a spolupracuje se skupinou při dosažení jejích cílu, potřeb a zájmů. Animátor posiluje kolektivní schopnost čelit problémům a řešit je, motivuje, 
mobilizuje, podporuje iniciativu, napomáhá k formování skupiny, v jejím upevňování a fungování ve společnosti. Zásadním předpokladem jeho práce s mládeží je porozumění světu mladých. Animátor je musí vnímat, poskytovat prostor pro rozvoj participace a rozvíjet jejich otevřenost. Použití metody kulturní animace se váže na skupinu jako výchovné prostředí, kde se členové mají navzájem pozitivně ovlivňovat, spolu komunikovat a překonávat životní problémy. Proto musí být kulturní animátor schopen kompetentně přistupovat $k$ práci se skupinou. Animační př́stup se nám jeví vhodný pro výchovu k volnému času, protože podobně jako informal education pomáhá najít a formulovat vlastní životní vizi a realizuje se ve skupině (komunitě).

Uvedené prvky jsou společné jak pro animaci, tak pro informal education (důraz na osobnost animátora, působení ve skupině). Koncepce informal education se nám jeví vhodná pro rozvoj volnočasové kompetence, protože pomáhá dětem a mladým lidem formulovat, přijmout a odůvodnit osobní cíle a převzít za ně společenskou odpovědnost. Pedagogika sociálního prostoru klade důraz na formování prostředí jako významného stimulujícího prvku. $\vee$ pedagogice sociálního prostoru jde o tvorbu a rozvoj prostředí, $v$ němž se mladí lidé mohou sami rozhodovat o svém volném čase, o jeho náplni a časovém rozvržení. Pedagog, který zohledňuje teorii sociálního prostoru, vyhledává a utváŕí bezpečné místo, které se stane pro skupinu/skupiny adolescentů životním prostorem. V rámci pedagogiky sociálního prostoru se děti a mladí lidé učí vnímat vliv sociálního a životního prostředí na vlastní vnímání času, komunikovat a spolupracovat ve skupině vrstevníků a samostatně utvářet svůj život. Všechny výše uvedené př́stupy jsou tedy vhodné pro práci s dětmi a mladými lidmi, která je zaměřená na volnočasovou kompetenci.

\section{Závěr}

Při učení postojovým kompetencím se nemůžeme omezit pouze na rozvoj technik k prímému osvojení kompetence. Primárně by pedagogičtí pracovníci měli usilovat o rozvoj sebepoznání, sebereflexe a komunikačních a sociálních schopností dětí.

Nejobtížnější je problematika postojových kompetencí, a to z důvodu, že v krátkodobém horizontu není možná jejich empirická evaluace, protože dosažení, príí. nedosažení cíle se v tomto prípadě projeví až za delší dobu. $V$ nějakém krátkodobém časovém horizontu lze pouze určit, zda se dítě přiblížilo či nepřiblížilo kstanovenému cíli; můžeme tedy hovořit spiše o rozšíření postojových kompetencí.

Ačkoliv jsme se v tomto př́spěvku zabývali téměř výhradně informální a neformální edukací, nechceme zapomenout ani na prostor formální edukace, kde se mohou plně rozvíjet kognitivní procesy a dispozice a rozšiřovat zkušenosti dětí s komunikací a spoluprací. Mezi volnočasové programy, ale i do školní výuky je třeba zařadit vzdělávací bloky nebo projekty, které pomohou účastníkům přemýšlet o volném čase a hodnotit, co v něm prožívají (reflexe volného času). Přitom se děti učí plánovat, hospodařit s časem, kriticky posuzovat volnočasové nabídky a uvědomovat si důležitost volného času pro sebe i společnost. $V$ takovém běžnodenním uplatňování dovedností získaných v rámci formálního vzdělávání, ale i z aktivit uskutečňovaných v rámci aktivit neformálního a informálního učení vidíme praktické naplnění požadavků na propojování formálního a neformálního vzdělávání, jak po něm volá Strategie vzdělávací politiky České republiky do roku 2030+. Pedagogické a jiné fakulty, kde se připravují na svoji profesi budoucí učitelé a jiní pedagogičtí pracovníci, by proto měly svým studentům dát možnost osvojit si v rámci studia problematiku volnočasové kompetence, a to prostřednictvím speciálních výukových bloků zaměřených na výchovu k volnému času. 


\section{Prohlášení o střetu zájmů}

Autoři nezaznamenali žádný potenciální střet zájmů.

\section{Literatura}

Bakešová, A. (2009). Filosofický slovník. Euromedia Group.

Bauman, P. (2006). Filosofické otázky v kurikulu základní školy. In J. Maňák \& T. Janík (Eds.), Problémy kurikula základní školy (s. 52-54). Masarykova Univerzita.

Borecký, V. (2005). Imaginace, hra a komika. Triton.

Boud, D. (2000). Experience-based learning. In G. Foley (Ed.), Understanding adult education and training (pp. 225-239). Allen \& Unwin.

Deinet, U. (2007). Sozialraumorientierung in der Offenen Kinder und Jugendarbeit. Info Animation, 11(4), 2-9. https://doj.ch/wp-content/uploads/InfoAnimation-11.pdf

Deinet, U., \& Krisch, R. (2002). Der sozialräumliche Blick der Jugendhilfe. Leske \& Budrich.

Deinet, U., \& Reutlinger, C. (2005). "Aneignung“ als Bildungskonzept der Sozialpädagogik. Verlag für Sozialwissenschaften.

Deterding, S., Dixon, D., Khaled, R., \& Nacke, L. (2011). From game design elements to gamefulness: Defining "gamification". In A. Lugmayr, H. Franssila, Ch. Safran, \& I. Hammouda (Eds.), Proceedings of the 15th International Academic MindTrek Conference: Envisioning Future Media Environments (pp. 9-15). ACM International Conference Proceeding Series. https://doi.org/10.1145/2181037.2181040

Dewey, J. (1938). Experience and education. Macmillan Co.

Dudová, A. (2018). Animace jako model komunitní práce. Fórum sociální práce, 9(2), 51-55.

Dudová, A., Kaplánek, M., \& Macků, R. (2011). Mnohotvarý fenomén animace. Pedagogická orientace, 21(3), 284-304.

Dudová, A., Kaplánek, M., \& Macků, R. (2014). Kulturní animace - filosofická východiska a praktické využití. Caritas et Veritas, 4(2), 60-68.

Fink, E. (1993). Hra jako symbol světa. Český spisovatel.

Franc, D., Martin, A., \& Zounková, D. (2007). Učení zážitkem a hrou. Computer Press.

Gillet, J.-C. (1998). Animation: der Sinn der Aktion. Verlag für Soziales und Kulturelles.

Google Forms. (n.d.). Metody výchovy ve volném čase. https://forms.gle/Qf7aeVagkNtiPKXg6

Hájek, B., Hofbauer, B., \& Pávková, J. (2008). Pedagogické ovlivňování volného času. Portál.

Hartl, P., \& Hartlová, H. (2000). Psychologický slovník. Portál.

Hofbauer, B. (2004). Děti, mládež a volný čas. Portál.

Hutchinson, S. (2014, August 29). What does it mean to "be" leisure literate? World Leisure Commission on Leisure Education (WLCLE). https://bit.ly/3BfkdaU

Institut dětí a mládeže MŠMT. (2000). Spontánní činnost ve SVČ. Metodický pokyn. (Rozpracováno).

IOWA Recreational Services. (n.d.). Lifetime Leisure Skills. https://recserv.uiowa.edu/lifetime-leisureskills

Jeffs, T., \& Smith, M. (2019). 'What is informal education?' The encyclopedia of pedagogy and informal education. Infed. https://infed.org/mobi/what-is-informal-education 
Jirásek, I. (2005). Významová diference prožitek - zážitek v Českém jazyce. In J. Kirchner (Ed.), Kontexty prožitku a kvalita života (s. 12-17). Univerzita J. E. Purkyně, Pedagogická fakulta.

Kaplánek, M. (2011). Volný čas jako výzva pro teologii. Studia theologica, 9(2), 97-117.

Kaplánek, M. (2012). Čas volnosti - čas výchovy. Portál.

Kaplánek, M. (2013). Animace. Portál.

Kaplánek, M. (2017). Volný čas a jeho význam ve výchově. Portál.

Kargul, J. (1995). Animacja społeczno-kulturalna. In T. Pilch \& I. Lepalczyk (Eds.), Pedagogika społeczna. Człowiek w zmieniajq̨cym się świecie (pp. 273-294). Żak.

Kolaříková, V. (2018). Konstruktivistické teorie učení a jejich využití v edukační realitě muzea. Pedagogická orientace, 28(3), 496-540. https://doi.org/10.5817/PedOr2018-3-496

Limbos, E. (1977). L'animation des groupes de culture et de loisirs. Entreprise moderned'édition.

Lipman, M. (1996). Natasha Vygotskian dialogues. Teachers College Press.

Lumsden, J., Edwards, E. A., Lawrence, N. S., Coyle, D., \& Munafò, M. R. (2016). Gamification of cognitive assessment and cognitive training: A systematic review of applications and efficacy. JMIR Serious Games, 4(2), e11. https://doi.org/10.2196/games.5888.

Maňák, J. (1990). Nárys didaktiky. PedF MU.

Mead, G. H. (1934). Mind, self and society from the standpoint of a social behaviorist. University of Chicago Press.

MŠMT. (2005, únor 9). Vyhláška MŠMT č. 74/2005 Sb., o zájmovém vzdělávání. https://www.msmt.cz/file/48249/

Munusturlar, S., \& Bayrak, C. (2017). Developing the Leisure Education Scale. World Leisure Journal, 59(4), 306-325. https://doi.org/10.1080/16078055.2016.1251489

Nahrstedt, W. (1974). Frezeitpädagogik in der nachindustriellen Gesellschaft 1. Historische Voraussetzungen und gegenwärtige Situation. Darmstadt: Luchterhand.

New Mexico Tech. (n.d.). Physical Recreation. https://www.nmt.edu/physrec

NIDM. (2007) Metodika pro podporu tvorby školního vzdělávacího programu ve školských zařízeních pro zájmové vzdělávání. https://docplayer.cz/3506367-Metodika-pro-podporu-tvorbyskolniho-vzdelavaciho-programu-ve-skolskych-zarizenich-pro-zajmove-vzdelavani.html

Opaschowski, H. (1976). Pädagogik der Freizeit. Klinkhard.

Opaschowski, H. (1979). Einführung in die freizeitkulturelle Breitenarbeit. Methoden und Modelle der Animation. Klinkhardt.

Opaschowski, H. (1996). Pädagogik der freien Lebenszeit. Leske \& Budrich.

Opaschowski, H. (2006). Einführung in die Freizeitwissenschaft. Verlag für Sozialwissenschaften.

Pelcová, N. (2000). Wilhelm Dilthey: Základy filosofie prožitku. Kreace.

Pieper, J. (2007). Muße und Kult. Kössel.

Pollo, M. (2005). Animazione culturale. LAS.

Prince George's Community College. (n.d.). Lifetime Fitness and Leisure Activities. https://www.pgcc.edu/programs-courses/courses/lifetime-fitness-and-leisure-activities

Průcha, J. (2009). Pedagogická encyklopedie. Portál.

Sennett, R. (2012). Together: the rituals, pleasures and politics of cooperation. Yale University Press. 
Slavík, J. (2007). Zážitková pedagogika - k čemu má smysl se vracet. Gymnasion, 4(8), 36-37.

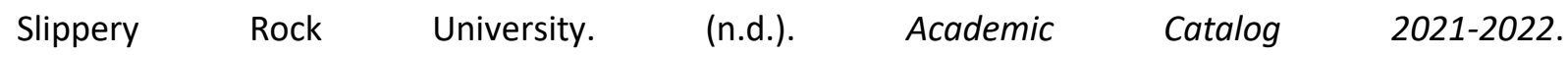
https://catalog.sru.edu/search/?search=leisure

Svatoš, V. (2006). Tak co, jak to šlo? Aneb Miniškola skupinových rozborů. Gymnasion, 3(5), 66-68.

TA ČR Starfos. (n.d.). Prožívání volného času dětí staršího školního věku jako výzva pro pedagogiku. https://starfos.tacr.cz/cs/project/TL02000387

University of Southern Maine. (n.d.). Department of Exercise, Health, and Sport Sciences. https://usm.maine.edu/ehss

Vážanský, M. (1992). Volný čas a pedagogika zážitku. Masarykova univerzita.

Zeyen, D., Odum, L. L., Lancaster, R. A., Fernandez, A., Tinker, S., \& Verhoven, P. J. (1997). Kangaroo kit: Leisure education curriculum. National Recreation and Park Associatio

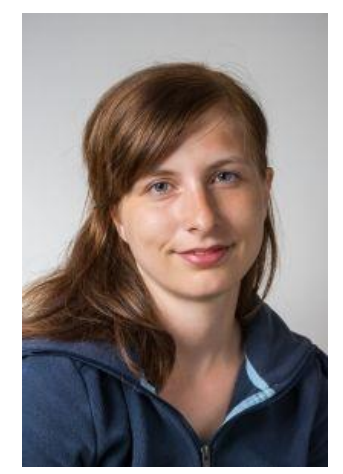

Mgr. Bc. Anna Dudová je odborná asistentka na Katedře pedagogiky Teologické fakulty Jihočeské university $v$ Českých Budějovicích. Věnuje se pedagogice volného času, kulturní animaci a nedirektivním metodám ve výchově.

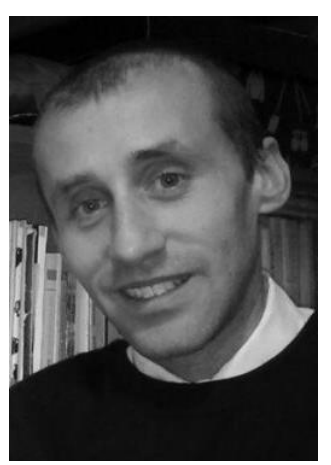

Mgr. Richard Macků, Ph.D. je odborným asistentem na Katedře pedagogiky Pedagogické fakulty Jihočeské univerzity, externě pracuje jako vědecký pracovník na Katedře pedagogiky Teologické fakulty téže univerzity. Odborně se věnuje práci s hrou i další problematice v oboru vychovatelství a zážitkové pedagogiky. 
Přiloha 1. Četnost využití metod výchovy ve volném čase
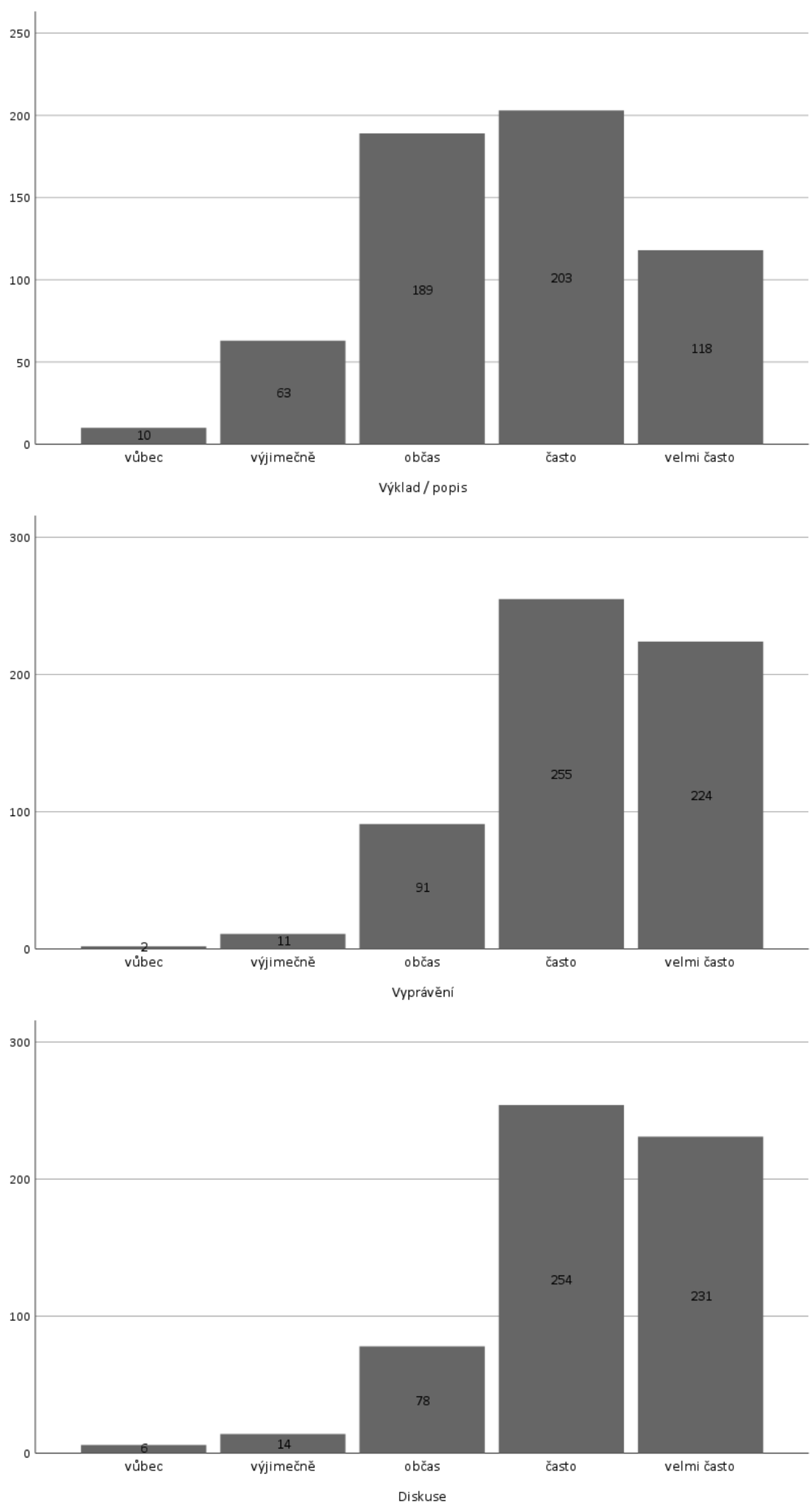

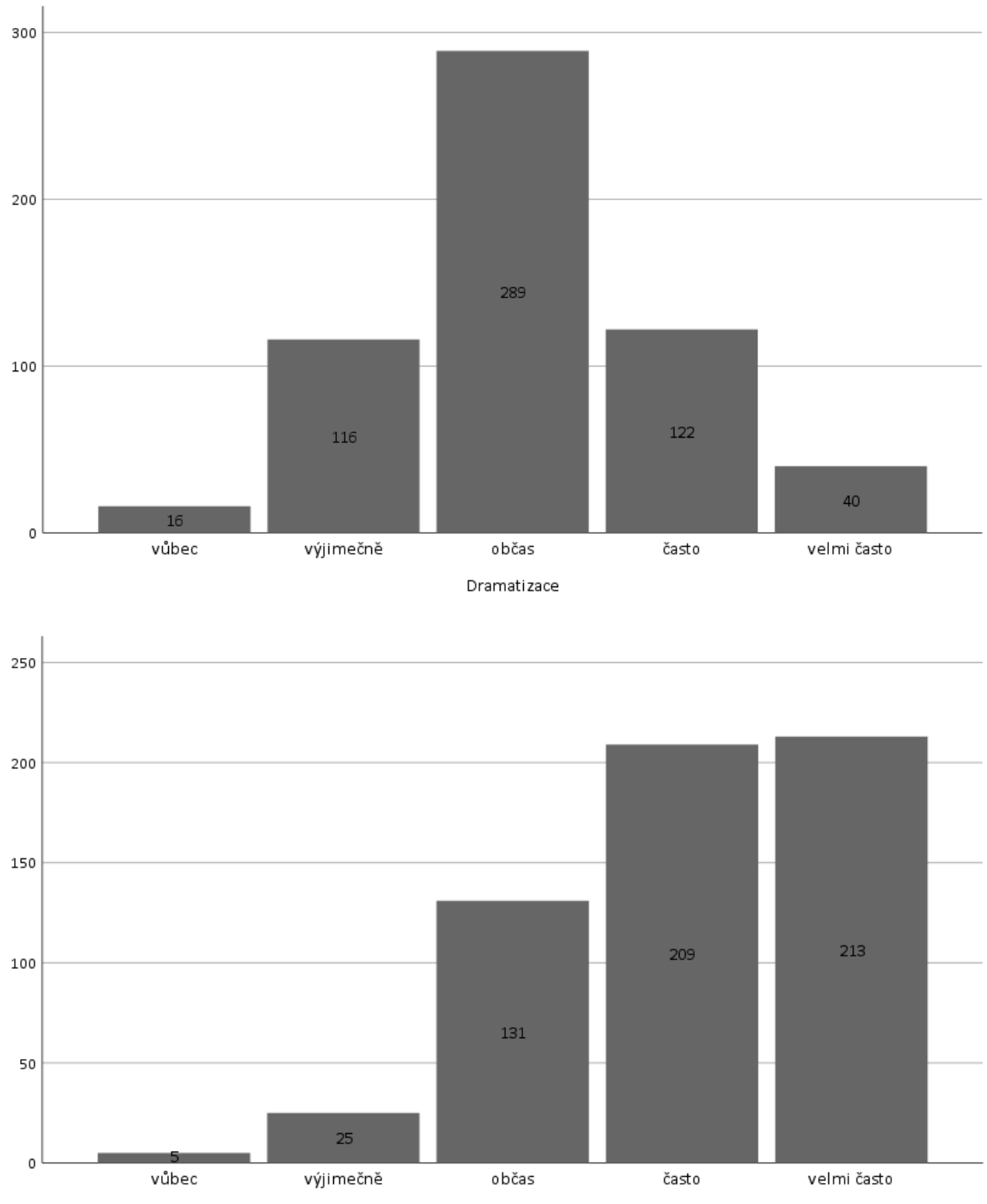

Práce sknihou/texty

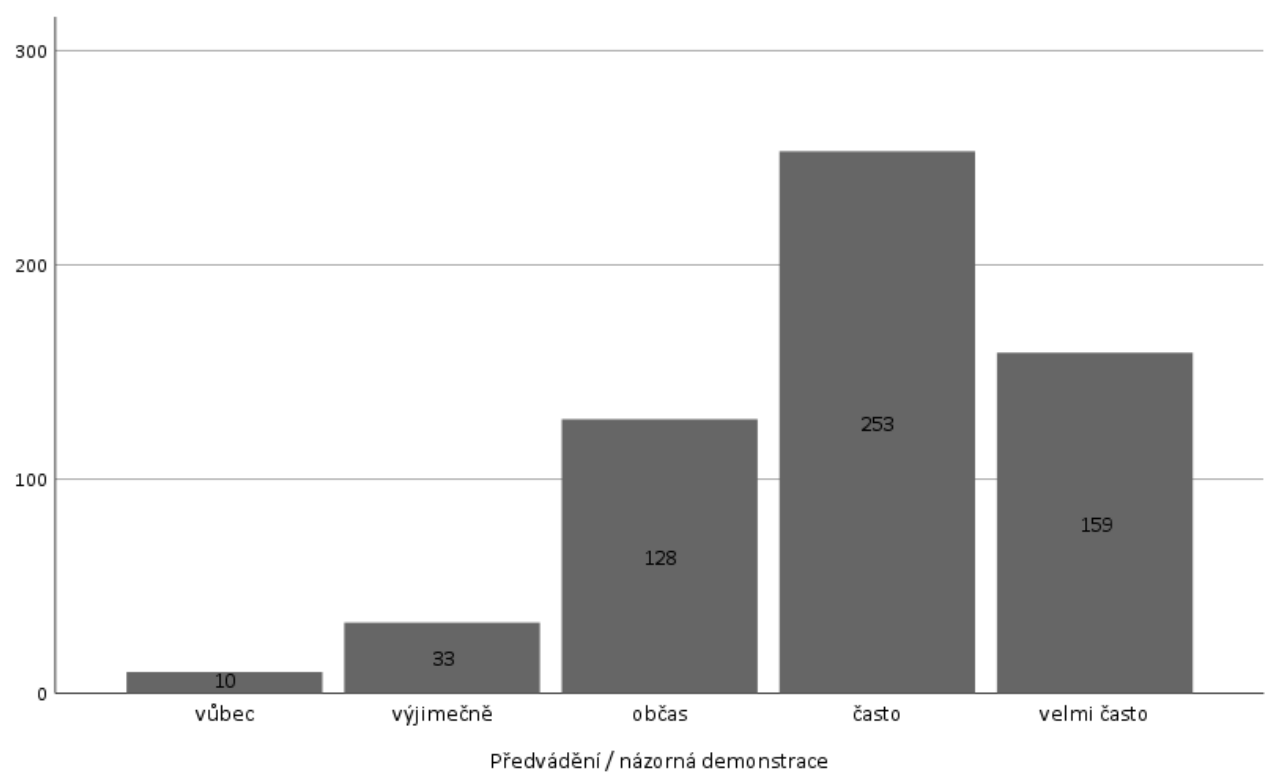



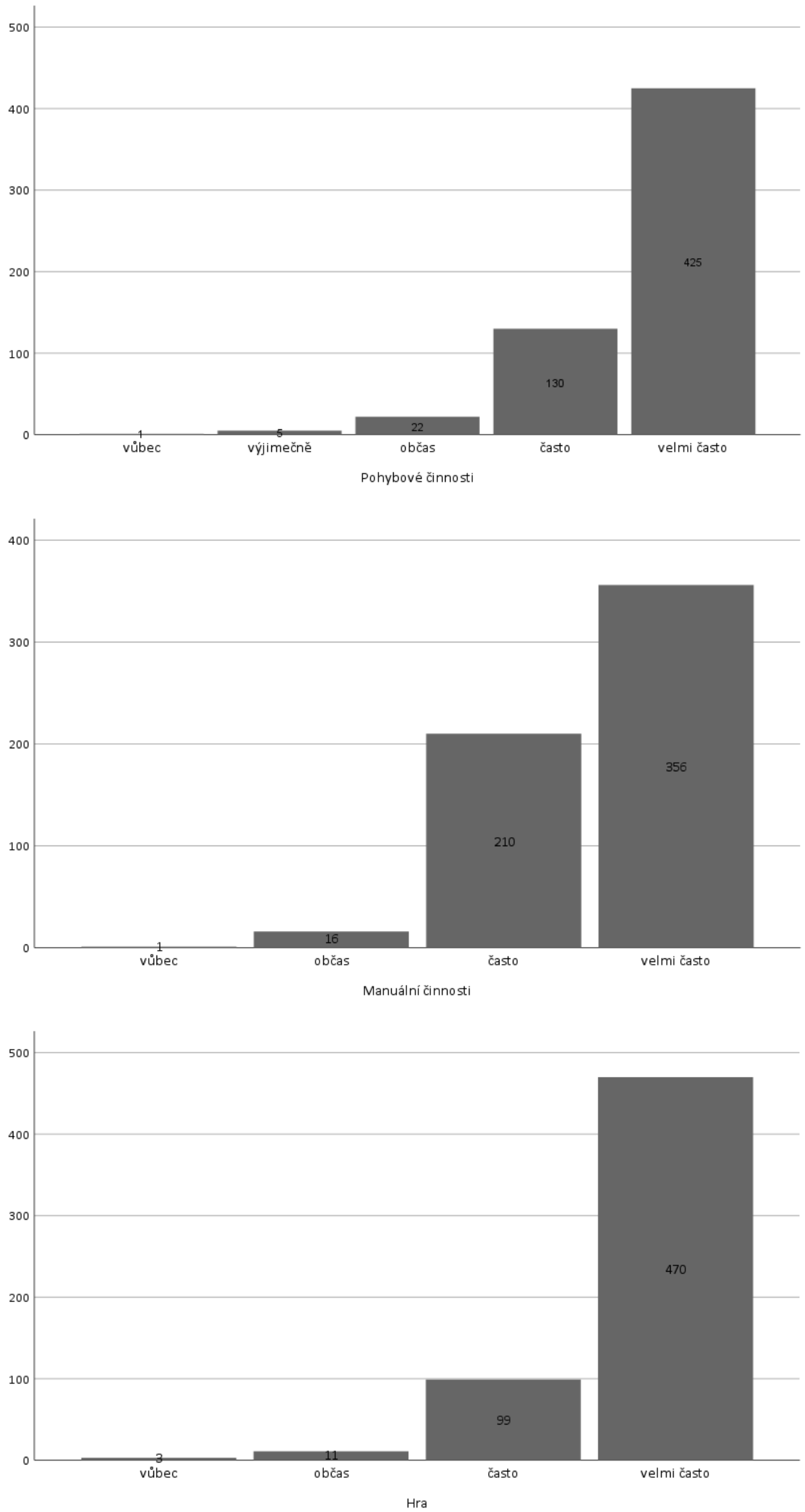